\title{
Perceived Stress and Its Impact on Health Behavior of Chinese Residents during the Epidemic of COVID-19: An Internet Survey
}

\author{
Yuerong Li ( $\sim$ liyuerong12@sohu.com) \\ Chongqing Medical University First Affiliated Hospital \\ Lili Yao \\ Chongqing Medical University First Affiliated Hospital \\ Yetao Luo \\ Chongqing Medical University Affiliated Children's Hospital \\ Feng Yuan \\ Chongqing Medical University Affiliated Children's Hospital \\ Lupei Yan \\ Chongqing Medical University Affiliated Children's Hospital
}

\section{Research}

Keywords: China, COVID-19, perceived stress, mental health, health behaviors

Posted Date: May 10th, 2020

DOl: https://doi.org/10.21203/rs.3.rs-27180/v1

License: () (1) This work is licensed under a Creative Commons Attribution 4.0 International License. Read Full License 


\section{Abstract}

Background An outbreak of 2019 novel coronavirus disease(COVID-19) could cause a severe respiratory illness, which may come from Spray or ordinary contact, then pose a great threat to life. Meanwhile, epidemic may trigger excessive stress and have a terrible impact on mental health even health behaviors, especially some special individuals. So this study paved the way for psychological interventions focused on specific groups during the COVID-19 epidemic.

Methods An internet survey was conducted on 2,449 residents in 20 provinces including Chongqing, Sichuan and Gansu et al, in order to collect the data of Chinese residents' perceived stress, COVID-19 awareness and health behaviors. SAS9.4 was used to analyze the relationship between health behaviors and perceived stress, and logistic regression was used to explore the influencing factors of health risk stress.

Results The residents' perceived stress score was 22.25 \pm 7.2(total score was 56), and the incidence of health risk stress was $39.89 \%$ (977/2449). As perceived stress increased, the frequency of health behaviors such as washing hands and wearing a mask decreased in turn. Age, cognition of susceptibility to COVID-19, life-threaten level, cognition of the importance of home isolation, and cognition of the difference between common cold and COVID-19 were related to the occurrence of health risk stress.

Conclusions There was a negative correlation between residents' health behaviors and perceived stress during the COVID-19 outbreak. It is of great significance to improve the public's awareness of the COVID-19, to provide good social support and psychological intervention for people with health risk stress and to promote their health behaviors.

\section{1.background}

Emerging infectious diseases pose public health risk across the globe. Outbreaks of Ebola in Africa, West Nile encephalitis in North America, severe acute respiratory syndrome (SARS) in Asia and Canada, and avian flu in Southeast Asia and China show that both developed and developing countries are constantly under the threat of infectious epidemics [1]. An outbreak of 2019 novel coronavirus disease(COVID-19)began in Wuhan, China, on December 8 , 2019, could cause a severe respiratory illness. On January 30, 2020, The World Health Organization(WHO) declared COVID-19 as the sixth public health emergency of international concern [2]. As of 10:00 CEST on May 2, 2020, there have been total 84388 confirmed cases (3 new), 4643 deaths (0 new)in China. Globally, Outside of China,there have been total 1492024 confirmed cases (30620 new), 7741 deaths (143 new) in Europe and 1340591 confirmed cases (48674 new), 72196 deaths (3109 new)in Americas. The risk of epidemic, at regional or global Level are still high [3]. Since COVID-19 infection may come from Spray or ordinary contact with strangers, colleagues, and even acquaintances, outbreaks could trigger stress and influence public perception of susceptibility, causing serious economic and social disruption. During the epidemic period, in order to reduce the risk of infection for more people, the government have introduced measures such as blocking cities, restricting travel, traffic control, home isolation, and canceling mass gathering activities. As time goes by, stress response of residents would undoubtedly result. The ability to identify stress can be beneficial to the individual as the first step toward the development of self-coping mechanisms. Stress can lead to lessened psychological well-being and deteriorating health [4]. Further, Studies have shown that people would change their behaviors due to obvious stress response. During the epidemic of SARS, due to the change of stress state, the public's living habits and behaviors have been changed to some extent, and the health risk stress state would lead people to adopt negative coping styles when facing public health emergencies [5]. Some researchers have also found that sudden public health incidents caused people to feel nervous to a certain extent and increased perceived stress, which was one of the key factors leading to changes and maintenance of individual's behavior. With the increase of stress, the overreaction behaviors would increase, and the adoption rates of health behaviors would be lower. Therefore, the psychological reaction of tension and loss of control would lead to the adverse overreaction to control events, which was not conducive to the formation of health behaviors [6]. Residents' perceived stress increased and their health behaviors decreased, which would not be beneficial to the prevention and control of the epidemic. In this work, we analyzed the current situation of Chinese residents' perceived stress and health behaviors, as well as the influencing factors of the incidence rate of health risk stress, so as to provide theoretical basis and reference foundation for psychological interventions during the epidemic.

\section{Methods}

\subsection{Aims}

The aims of the study were: (1) to discover high-risk populations whose perceived stress was high and put forward a number of suggestions for psychological interventions worth reference; (2) to assess the prevalence of health risk stress and its impact on mental health; (3) to examine the relationships between perceived stress and health behaviors of Chinese residents during the COVID-19 epidemic.

\subsection{Study design and Participant}

This study conducted an internet survey on perceived stress and health behaviors of 2449 Chinese residents, from February 14 to February $22,2020$. Participants were enrolled voluntarily, but not selected randomly, nevertheless, we strived to avoid any systematic selection bias, and the research sample chosen should represent Chinese residents as much as possible. The selection criteria for recruitment included: Urban and rural residents over the age of 18 , and both genders. Medical workers, teachers, company employees, students, workers, farmers, service industry people and other occupational groups were also eligible. Accordingly, exclusion criteria were applied, Residents who were unable to use computers, smart phones and other electronic devices were excluded, In addition, individuals with anxiety, depression, schizophrenia and other mental diseases were also excluded.

\subsection{Measures}


Demographic Variables. Including gender, age, marital status, educational level, et al. Table 1. We intended to know the current status of perceived stress and the incidence of health risk stress among Chinese residents with different demographic characteristics. 
Table 1

Comparison of Perceived Stress and Incidence of Health Risk Stress among Participants with Different Demographic Characteristics

\begin{tabular}{|c|c|c|c|c|c|c|c|c|c|}
\hline Variable & & & $\mathbf{N}$ & $\begin{array}{l}\text { perceived } \\
\text { stress } \\
\text { score }\end{array}$ & $t / F$ & $P$ & $\begin{array}{l}\text { Health risk } \\
\text { stress }\end{array}$ & $x^{2}$ & $\mathbf{P}$ \\
\hline \multirow[t]{2}{*}{ gender } & & Male & 823 & $\begin{array}{l}21.55 \pm \\
7.57\end{array}$ & -3.324 & 0.001 & $315(38.27)$ & 1.355 & 0.244 \\
\hline & & Female & 1626 & $\begin{array}{l}22.6 \pm \\
6.99\end{array}$ & & & 662(40.71) & & \\
\hline \multirow[t]{5}{*}{ age(years) } & a & $18-25$ & 837 & $\begin{array}{l}23.78 \pm \\
6.24 \mathrm{cde}\end{array}$ & 28.47 & $<.001$ & 409(48.86)cde & 70.11 & $<.001$ \\
\hline & $b$ & $26-30$ & 463 & $\begin{array}{l}23.33 \pm \\
6.67 \mathrm{cde}\end{array}$ & & & 209(45.14)cde & & \\
\hline & $c$ & $31-40$ & 427 & $\begin{array}{l}21.31 \pm \\
7.82 a b d\end{array}$ & & & 140(32.79)ab & & \\
\hline & $d$ & $41-50$ & 486 & $\begin{array}{l}20.1 \pm \\
7.98 \mathrm{abc}\end{array}$ & & & 150(30.86)ab & & \\
\hline & e & $\geqq 51$ & 236 & $\begin{array}{l}20.77 \pm \\
6.95 \mathrm{ab}\end{array}$ & & & $69(29.24) a b$ & & \\
\hline \multirow[t]{5}{*}{ Provinces } & a & Chongqing & 1408 & $\begin{array}{l}22.72 \pm \\
7.03 b\end{array}$ & 6.068 & $\begin{array}{l}< \\
0.001\end{array}$ & $603(42.83) b$ & 13.87 & 0.008 \\
\hline & $b$ & Sichuan & 434 & $\begin{array}{l}20.84 \pm \\
7.69 \mathrm{ac}\end{array}$ & & & 147(33.87)a & & \\
\hline & c & Gansu & 151 & $\begin{array}{l}22.69 \pm \\
7.3 b\end{array}$ & & & $59(39.07)$ & & \\
\hline & $d$ & Jiangxi & 114 & $\begin{array}{l}21.72 \pm \\
7.58\end{array}$ & & & $45(39.47)$ & & \\
\hline & e & Others & 342 & $\begin{array}{l}22.07 \pm \\
6.89\end{array}$ & & & 123(35.96) & & \\
\hline \multirow[t]{3}{*}{ Marital status } & a & Non-married & 1000 & $\begin{array}{l}23.54 \pm \\
6.42 \mathrm{bc}\end{array}$ & 27.8 & $<.001$ & 471(47.10)b & 36.62 & $<0.001$ \\
\hline & $b$ & Married & 1353 & $\begin{array}{l}21.35 \pm \\
7.5 a\end{array}$ & & & 473(34.96)a & & \\
\hline & c & Divorced or widowed & 96 & $\begin{array}{l}21.48 \pm \\
8.58 a\end{array}$ & & & 33(34.38) & & \\
\hline \multirow[t]{3}{*}{ Education level } & a & $\begin{array}{l}\text { Junior high school } \\
\text { diploma or below }\end{array}$ & 374 & $\begin{array}{l}20.77 \pm \\
8 \mathrm{bc}\end{array}$ & 9.318 & $<0.001$ & 135(36.10) & 3.072 & 0.215 \\
\hline & $b$ & $\begin{array}{l}\text { Senior high school } \\
\text { diploma or Advanced } \\
\text { diploma }\end{array}$ & 1038 & $\begin{array}{l}22.47 \pm \\
7.04 a\end{array}$ & & & $414(39.88)$ & & \\
\hline & c & $\begin{array}{l}\text { Baccalaureate degree } \\
\text { and above }\end{array}$ & 1037 & $\begin{array}{l}22.55 \pm \\
7 a\end{array}$ & & & $428(41.27)$ & & \\
\hline \multirow[t]{3}{*}{ Occupation } & a & Medical staff & 312 & $\begin{array}{l}22.49 \pm \\
6.05 \mathrm{bc}\end{array}$ & 11.583 & $<.001$ & 141(45.19)c & 20.147 & $<001$ \\
\hline & $b$ & Student & 261 & $\begin{array}{l}23.87 \pm \\
6.18 \mathrm{ac}\end{array}$ & & & 127(48.66)c & & \\
\hline & c & Others & 1867 & $\begin{array}{l}21.64 \pm \\
7.61 \mathrm{ab}\end{array}$ & & & 685(36.51)ab & & \\
\hline \multirow[t]{4}{*}{ Monthly income(RMB) } & a & $\leqq 3000$ & 845 & $\begin{array}{l}22.64 \pm \\
7.33 e\end{array}$ & 2.762 & 0.026 & $362(42.84) \mathrm{e}$ & 12.54 & 0.014 \\
\hline & $b$ & $3000-5000$ & 880 & $\begin{array}{l}22.31 \pm \\
7.3 e^{-}\end{array}$ & & & $356(40.45)$ & & \\
\hline & c & $5000-7000$ & 365 & $\begin{array}{l}22.09 \pm \\
6.6 \mathrm{e}\end{array}$ & & & 140(38.36) & & \\
\hline & $d$ & $7000-10000$ & 215 & $\begin{array}{l}21.8 \pm \\
7.21 \mathrm{e}\end{array}$ & & & $78(36.28)$ & & \\
\hline
\end{tabular}

a: compared with the first layer, $P<0.05$; b: compared with the second layer, $P<0.05$; : compared with the third layer, $P<0.05$; $\mathrm{d}$ : compared with the fourth layer, $P<0.05$; e: compared with the fifth layer, $P<0.05$; : compared with the sixth layer, $P<0.05$. 


\begin{tabular}{|c|c|c|c|c|c|c|c|c|c|}
\hline \multirow[t]{2}{*}{ Variable } & \multicolumn{2}{|c|}{ Label } & \multirow{2}{*}{$\begin{array}{l}\mathbf{N} \\
144\end{array}$} & \multirow{2}{*}{$\begin{array}{l}\begin{array}{l}\text { perceived } \\
\text { stress } \\
\text { score }\end{array} \\
20.6 \pm \\
7.15 \mathrm{abcd}\end{array}$} & \multirow[t]{2}{*}{$t / F$} & \multirow[t]{2}{*}{$\mathbf{P}$} & \multirow{2}{*}{$\begin{array}{l}\begin{array}{l}\text { Health risk } \\
\text { stress }\end{array} \\
41(28.47) a\end{array}$} & \multirow[t]{2}{*}{$x^{2}$} & \multirow[t]{2}{*}{$\mathbf{P}$} \\
\hline & e & $\$ 10000$ & & & & & & & \\
\hline \multirow[t]{3}{*}{ Residence } & a & Urban & 1783 & $\begin{array}{l}22.29 \pm \\
7.16\end{array}$ & 0.155 & 0.857 & 709(39.76) & 0.101 & 0.951 \\
\hline & b & Township & 394 & $\begin{array}{l}22.19 \pm \\
7.13\end{array}$ & & & $160(40.61)$ & & \\
\hline & c & Rural & 272 & $\begin{array}{l}22.04 \pm \\
7.59\end{array}$ & & & 108(39.71) & & \\
\hline \multirow[t]{2}{*}{$\begin{array}{l}\text { Whether there are medical staff in the } \\
\text { family? }\end{array}$} & & Yes & 940 & $\begin{array}{l}22.52 \pm \\
6.91\end{array}$ & 1.529 & 0.126 & $391(41.60)$ & 1.843 & 0.175 \\
\hline & & No & 1509 & $\begin{array}{l}22.07 \pm \\
7.38\end{array}$ & & & $586(38.83)$ & & \\
\hline \multirow{2}{*}{$\begin{array}{l}\text { Are you in the medical isolation } \\
\text { observation period or the home } \\
\text { isolation observation period? }\end{array}$} & & Yes & 246 & $\begin{array}{l}23.65 \pm \\
6.59\end{array}$ & 3.231 & 0.001 & $115(46.75)$ & 5.358 & 0.021 \\
\hline & & No & 2203 & $\begin{array}{l}22.09 \pm \\
7.25\end{array}$ & & & $862(39.13)$ & & \\
\hline \multirow{2}{*}{$\begin{array}{l}\text { Have you experienced medical } \\
\text { isolation observation period or home } \\
\text { isolation observation period? }\end{array}$} & & Yes & 226 & $\begin{array}{l}22.64 \pm \\
6.96\end{array}$ & 0.867 & 0.386 & $100(44.25)$ & 1.968 & 0.161 \\
\hline & & No & 2223 & $\begin{array}{l}22.21 \pm \\
7.23\end{array}$ & & & $877(39.45)$ & & \\
\hline
\end{tabular}

\section{Chinese perceived stress scale (CPSS)}

The perceived stress scale (PSS) was developed by American psychologist Dr. Cohen s [7] to assess the degree of stress caused by unpredictable, uncontrollable or overloaded life. Currently, there are 3 versions of 14 items (PSS-14), 10 items (PSS-10) and 4 items (PSS-4), PSS-14 is considered as a brief and easy scale to administer and complete [8]. Considering the national conditions and the local environment, in this study, we used the version of Chinese perceived stress scale (CPSS). The scale(PSS-14) was first translated by two domestic scholars, then translated back by two Chinese-American scholars, and lastly reviewed by one Chinese-American and one domestic scholar. The overall structure and specific items were examined and necessary modifications were made according to China's cultural background to form a preliminary scale, which had good reliability and validity after investigation [9], so CPSS was used to investigate the perceived stress of residents during the epidemic of COVID-19, including 14 items, each item had 5 options: never, almost, sometimes, often, always, corresponding to 0 to 4 points respectively. The highest possible score was 56 , because positive questions were scored from 4 to 0 , while negative questions were scored in reverse. Positive items assessed the ability to respond to perceived stress, while negative element focused on assessing lack of control, negative emotions, and reactions. Take 25 points as the critical value, low stress state (0-score), medium stress state (15-score) and health risk stress state (above 25 score). That is, the higher the score, the greater perceived stress of the residents during the epidemic. After the reliability test, the Cronbach coefficient of the scale in this survey was 0.829 , which had a high internal consistency.

\section{COVID-19 Cognition and Health Behavior Questionnaires}

We referred to the relevant literatures on the prevention and treatment of infectious diseases and World Health Organization(WHO) and the National Health Committee of the People's Republic of China on the prevention of COVID-19 [10-13], The rationality and scientificity of questionnaire item design were communicated online by research team. Secondly, we conducted a small-scale test of the online questionnaire to understand the response time and the feelings of the respondents, deleted misleading or excessive items, and increased the feasibility of the survey. Finally, 13 cognitive items and 10 health behaviors items for the COVID-19 were drawn up. The Cronbach coefficient of two questionnaires were 0.667 and 0.827 , respectively.

\subsection{Statistical analysis}

The measurement data of normal distribution were described by the mean plus or minus standard deviation. The comparison between groups adopted two independent samples $T$ test and variance analysis, and the afterwards two-two comparison adopted SNK method. The measurement data were described by the rate of adoption, the chi-square analysis was used for the comparison between groups, and Bonferroni method was used for the subsequent two-totwo comparison. The linear trend test was used to examine the relationship between health behaviors and perceived stress, and the Gamma coefficient described the correlation between health behaviors and perceived stress, Variables with $P<0.05$ in univariate logistic regression were included in multivariate logistic regression, and the independent risk factors of health risk stress were examined by stepwise regression (exclusion standard 0.05$) . P<$ 0.05 was considered statistically significant. All analyses were analyzed in SAS9.4. (Copyright 2016 SAS Institute Inc. Cary, NC, USA) $P<0.05$ was considered statistically significant.

\subsection{Research quality control}


We adopted a series of measures for strict quality control.1). Each item was set as a required answer, otherwise it could not be submitted; 2). Avoid repeated submission and filling, each user could only answer once; 3 ). Eliminate invalid questionnaires (logical errors, answer time less than 1 minute or more than 30 minutes)

\section{3.results}

In this study, 2,533 internet questionnaires were collected, of which 2,449 were valid and been input into database for data analysis, with an effective rate of $96.7 \%$. There was a negative correlation between health behavior and perceived stress, $39.89 \%$ of the residents were in a state of health risk stress.

\subsection{Demographic characteristics \& perceived stress}

Among the valid samples, $823(33.60 \%)$ were male and $1626(66.39 \%)$ were female. $90.4 \%$ of the residents are aged between 18 and 50 . There were 1,783 urban residents, accounting for $72.8 \%, 666$ township and rural residents, accounting for $27.2 \% .374$ (15.3\%) residents with junior high school education or below, and 2,075 (84.7\%) residents with senior high school education or above were recruited. In sociodemographic data, gender, age, marital status, education level, and the analysis of perceived stress are statistically significant. $P<0.05$. Totally, through this research, we have found at least three types of residents with extremely high stress. The results showed that the female residents' perceived stress score (22.6 \pm 6.99$)$ was higher than that of the male residents, but there was no statistical difference in the incidence of health risk stress between the two groups. The residents aged 18 to 25 years old had higher perceived stress $(23.78 \pm 6.24)$ and health risk stress incidence $(48.86 \%)$ than those aged over 30 years old. Compared with other occupations, students had the strongest perceived stress $(23.87 \pm 6.18)$, and $48.66 \%$ of students are in a state of health risk stress. Table 1 . Besides, residents who were in the medical isolation or the home isolation observation period had higher perceived stress $(23.65 \pm 6.59)$ than those who were not in isolation. Further, this study showed that $45.19 \%$ of medical workers were in a state of health risk stress.

\section{2 health behaviors \& perceived stress}

There was a negative correlation between health behavior and perceived stress, the Gamma correlation coefficient is between - 0.212 and -0.379 . With the increased of perceived stress, the frequency of residents' health behaviors decreased in order. such as washing hands, wearing a mask et al. The data showed that the residents who never or occasionally paid attention to the real-time information of COVID-19 had the lowest incidence of health risk stress $(0.1 \%)$, and the residents who always wore a mask when going out had the highest incidence of health risk stress (74.41\%). Table 2 . 
Table 2

Comparison of participants' health behaviors under different stress states

\begin{tabular}{|c|c|c|c|c|c|c|c|c|c|c|c|}
\hline & Frequency & total & Low stress & $\begin{array}{l}\text { Medium } \\
\text { stress }\end{array}$ & $\begin{array}{l}\text { Health risk } \\
\text { stress }\end{array}$ & $x^{2}$ & $\mathbf{P}$ & $x^{2 *}$ & $\mathbf{P}$ & $\begin{array}{l}\text { Gamms } \\
\text { coefficient }\end{array}$ & $\mathbf{P}$ \\
\hline \multirow{4}{*}{$\begin{array}{l}\text { Active } \\
\text { Attention to } \\
\text { Real-time } \\
\text { Information } \\
\text { of COVID- } \\
19\end{array}$} & $\begin{array}{l}\text { Never or } \\
\text { Occasionally }\end{array}$ & $2(0.08)$ & $0(0.00)$ & $1(0.09)$ & $1(0.10)$ & 33.647 & $\begin{array}{l}< \\
0.001\end{array}$ & 28.902 & $\begin{array}{l}< \\
0.001\end{array}$ & -0.223 & $\begin{array}{l}< \\
0.001\end{array}$ \\
\hline & Sometimes & $52(2.12)$ & $6(1.70)$ & $17(1.52)$ & $29(2.97)$ & & & & & & \\
\hline & Often & $501(20.46)$ & $40(11.36)$ & 225(20.09) & $236(24.16)$ & & & & & & \\
\hline & Always & 1894(77.34) & $306(86.93)$ & $877(78.30)$ & 711(72.77) & & & & & & \\
\hline \multirow{4}{*}{$\begin{array}{l}\text { After the } \\
\text { outbreak, } \\
\text { take the } \\
\text { initiative to } \\
\text { advise } \\
\text { family } \\
\text { members } \\
\text { to wash } \\
\text { hands } \\
\text { frequently, } \\
\text { wear } \\
\text { masks and } \\
\text { other } \\
\text { protective } \\
\text { measures }\end{array}$} & $\begin{array}{l}\text { Never or } \\
\text { Occasionally }\end{array}$ & 83(3.39) & $5(1.42)$ & $22(1.96)$ & $56(5.73)$ & 120.569 & $\begin{array}{l}<.001 \\
0.001\end{array}$ & 107.782 & $\begin{array}{l}< \\
0.001\end{array}$ & -0.339 & $\begin{array}{l}< \\
0.001\end{array}$ \\
\hline & Sometimes & $119(4.86)$ & $4(1.14)$ & $41(3.66)$ & 74(7.57) & & & & & & \\
\hline & Often & $774(31.60)$ & 64(18.18) & $354(31.61)$ & $356(36.44)$ & & & & & & \\
\hline & Always & $1473(60.15)$ & $279(79.26)$ & $703(62.77)$ & 491(50.26) & & & & & & \\
\hline \multirow{4}{*}{$\begin{array}{l}\text { Wash } \\
\text { hands } \\
\text { frequently } \\
\text { at home }\end{array}$} & $\begin{array}{l}\text { Never or } \\
\text { Occasionally }\end{array}$ & $64(2.61)$ & $4(1.14)$ & 11(0.98) & $49(5.02)$ & 122.946 & $<.001$ & 105.023 & $<.001$ & -0.31 & $\begin{array}{l}<.001 \\
0.00\end{array}$ \\
\hline & Sometimes & 137(5.59) & $9(2.56)$ & $45(4.02)$ & $83(8.50)$ & & & & & & \\
\hline & Often & $1029(42.02)$ & $98(27.84)$ & $485(43.30)$ & $446(45.65)$ & & & & & & \\
\hline & Always & 1219(49.78) & 241(68.47) & $579(51.70)$ & $399(40.84)$ & & & & & & \\
\hline \multirow{4}{*}{$\begin{array}{l}\text { Pay } \\
\text { attention to } \\
\text { open } \\
\text { windows } \\
\text { and } \\
\text { ventilate at } \\
\text { home (at } \\
\text { least twice } \\
\text { a day) }\end{array}$} & $\begin{array}{l}\text { Never or } \\
\text { Occasionally }\end{array}$ & $67(2.74)$ & $5(1.42)$ & 21(1.88) & $41(4.20)$ & 103.891 & $<.001$ & 88.838 & $<.001$ & -0.3 & $\dot{0} .001$ \\
\hline & Sometimes & $164(6.70)$ & $12(3.41)$ & $56(5.00)$ & $96(9.83)$ & & & & & & \\
\hline & Often & $951(38.83)$ & $85(24.15)$ & $443(39.55)$ & $423(43.30)$ & & & & & & \\
\hline & Always & $1267(51.74)$ & $250(71.02)$ & $600(53.57)$ & $417(42.68)$ & & & & & & \\
\hline \multirow{4}{*}{$\begin{array}{l}\text { Keep a safe } \\
\text { distance } \\
\text { from } \\
\text { strangers } \\
\text { when going } \\
\text { out (at } \\
\text { least 1 } \\
\text { meter) }\end{array}$} & $\begin{array}{l}\text { Never or } \\
\text { Occasionally }\end{array}$ & $96(3.92)$ & $9(2.56)$ & $25(2.23)$ & $62(6.35)$ & 138.724 & $\begin{array}{l}< \\
0.001\end{array}$ & 110.082 & $\begin{array}{l}< \\
0.001\end{array}$ & -0.327 & $\begin{array}{l}< \\
0.001\end{array}$ \\
\hline & Sometimes & $236(9.64)$ & 14(3.98) & $91(8.13)$ & $131(13.41)$ & & & & & & \\
\hline & Often & $824(33.65)$ & $62(17.61)$ & $398(35.54)$ & $364(37.26)$ & & & & & & \\
\hline & Always & $1293(52.80)$ & $267(75.85)$ & $606(54.11)$ & $420(42.99)$ & & & & & & \\
\hline
\end{tabular}




\begin{tabular}{|c|c|c|c|c|c|c|c|c|c|c|c|}
\hline & Frequency & total & Low stress & $\begin{array}{l}\text { Medium } \\
\text { stress }\end{array}$ & $\begin{array}{l}\text { Health risk } \\
\text { stress }\end{array}$ & $x^{2}$ & $\mathbf{P}$ & $x^{2 *}$ & $\mathbf{P}$ & $\begin{array}{l}\text { Gamms } \\
\text { coefficient }\end{array}$ & $P$ \\
\hline \multirow{4}{*}{$\begin{array}{l}\text { Cover } \\
\text { mouth and } \\
\text { nose with a } \\
\text { tissue or } \\
\text { elbow } \\
\text { when } \\
\text { coughing } \\
\text { or sneezing } \\
\text { to avoid } \\
\text { others }\end{array}$} & $\begin{array}{l}\text { Never or } \\
\text { Occasionally }\end{array}$ & $67(2.74)$ & $4(1.14)$ & 19(1.70) & $44(4.50)$ & 135.224 & $\begin{array}{l}< \\
0.001\end{array}$ & 111.793 & $\begin{array}{l}< \\
0.001\end{array}$ & -0.379 & $\begin{array}{l}< \\
0.001\end{array}$ \\
\hline & Sometimes & $120(4.90)$ & $9(2.56)$ & $27(2.41)$ & $84(8.60)$ & & & & & & \\
\hline & Often & $622(25.40)$ & 46(13.07) & $271(24.20)$ & 305(31.22) & & & & & & \\
\hline & Always & $1640(66.97)$ & 293(83.24) & $803(71.70)$ & $544(55.68)$ & & & & & & \\
\hline \multirow{4}{*}{$\begin{array}{l}\text { Wear a } \\
\text { mask when } \\
\text { going out }\end{array}$} & $\begin{array}{l}\text { Never or } \\
\text { Occasionally }\end{array}$ & $44(1.80)$ & $2(0.57)$ & $16(1.43)$ & $26(2.66)$ & 68.996 & $\begin{array}{l}< \\
0.001\end{array}$ & 51.648 & $\begin{array}{l}< \\
0.001\end{array}$ & -0.352 & $\begin{array}{l}< \\
0.001\end{array}$ \\
\hline & Sometimes & 83(3.39) & $9(2.56)$ & $24(2.14)$ & $50(5.12)$ & & & & & & \\
\hline & Often & $313(12.78)$ & $24(6.82)$ & $115(10.27)$ & 174(17.81) & & & & & & \\
\hline & Always & $2009(82.03)$ & $317(90.06)$ & $965(86.16)$ & 727(74.41) & & & & & & \\
\hline \multirow{4}{*}{$\begin{array}{l}\text { Have } \\
\text { health } \\
\text { Diets to } \\
\text { improve } \\
\text { nutrition } \\
\text { level }\end{array}$} & $\begin{array}{l}\text { Never or } \\
\text { Occasionally }\end{array}$ & $103(4.21)$ & $4(1.14)$ & 21(1.88) & 78(7.98) & 217.075 & $\begin{array}{l}<.001 \\
0.00\end{array}$ & 179.163 & $\begin{array}{l}<.001 \\
0.00\end{array}$ & -0.371 & $<0.001$ \\
\hline & Sometimes & $363(14.82)$ & $16(4.55)$ & 124(11.07) & $223(22.82)$ & & & & & & \\
\hline & Often & $981(40.06)$ & 107(30.40) & $507(45.27)$ & $367(37.56)$ & & & & & & \\
\hline & Always & $1002(40.91)$ & $225(63.92)$ & $468(41.79)$ & $309(31.63)$ & & & & & & \\
\hline \multirow{4}{*}{$\begin{array}{l}\text { Take } \\
\text { appropriate } \\
\text { exercise at } \\
\text { home }\end{array}$} & $\begin{array}{l}\text { Never or } \\
\text { Occasionally }\end{array}$ & 489(19.97) & $36(10.23)$ & $180(16.07)$ & 273(27.94) & 166.904 & $<.001$ & 143.359 & $\begin{array}{l}< \\
0.001\end{array}$ & -0.31 & $\begin{array}{l}< \\
0.001\end{array}$ \\
\hline & Sometimes & 654(26.70) & $55(15.63)$ & $299(26.70)$ & $300(30.71)$ & & & & & & \\
\hline & Often & 694(28.34) & 104(29.55) & $364(32.50)$ & 226(23.13) & & & & & & \\
\hline & Always & 612(24.99) & $157(44.60)$ & $277(24.73)$ & 178(18.22) & & & & & & \\
\hline \multirow{4}{*}{$\begin{array}{l}\text { Reduce } \\
\text { group } \\
\text { gathering } \\
\text { activities } \\
\text { such as } \\
\text { going out } \\
\text { and } \\
\text { gathering }\end{array}$} & $\begin{array}{l}\text { Never or } \\
\text { Occasionally }\end{array}$ & 448(18.29) & $60(17.05)$ & 185(16.52) & 203(20.78) & 77.653 & $\begin{array}{l}< \\
0.001\end{array}$ & 26.898 & $\begin{array}{l}< \\
0.001\end{array}$ & -0.212 & $<0.001$ \\
\hline & Sometimes & 89(3.63) & $4(1.14)$ & $24(2.14)$ & $61(6.24)$ & & & & & & \\
\hline & Often & $317(12.94)$ & $16(4.55)$ & 152(13.57) & 149(15.25) & & & & & & \\
\hline & Always & 1595(65.13) & 272(77.27) & 759(67.77) & $564(57.73)$ & & & & & & \\
\hline
\end{tabular}

\subsection{Cognition of COVID-19 \& perceived stress}

Nowadays, the confirmed transmission routes of the virus include droplet transmission and contact transmission of COVID-19. However, aspect of COVID19 cognition, $74.27 \%-80.93 \%$ of residents could correctly answer whether taking antibiotics / Shuanghuanglian oral solution could prevent COVID-19, whether vinegar could kill the virus, and whether hot water at 56 degrees Celsius could kill the virus for 30 minutes, It can be seen that residents had a certain ability to identify rumors. But only $15.3 \%$ of the residents knew the route of transmission of the virus, $13.1 \%$ of the residents knew the masks that could prevent the virus from spreading, and the overall disease awareness rate was $62.04 \%$. At the same time, this survey have shown that different cognitive levels of COVID-19 could affect perceived stress score and the incidence of health risk stress. Table 3. 
Table 3

The status quo of disease cognition and its comparison with the incidence of perceived stress and health risk stress

\begin{tabular}{|c|c|c|c|c|c|c|c|c|c|}
\hline & Label & & $\mathbf{N}$ & $\begin{array}{l}\text { Perceived } \\
\text { stress } \\
\text { score }\end{array}$ & $t / F$ & $\mathbf{P}$ & $\begin{array}{l}\text { Health risk } \\
\text { stress }\end{array}$ & $x^{2}$ & $\mathbf{P}$ \\
\hline \multirow[t]{2}{*}{$\begin{array}{l}\text { In general, is the longest incubation } \\
\text { period for COVID-19 } 14 \text { days? }\end{array}$} & & No or Unclear & 198 & $\begin{array}{l}23.74 \pm \\
6.58\end{array}$ & 3.044 & 0.002 & $95(47.98)$ & 5.874 & 0.015 \\
\hline & & Yes & 2251 & $\begin{array}{l}22.11 \pm \\
7.24\end{array}$ & & & 882(39.18) & & \\
\hline \multirow{2}{*}{$\begin{array}{l}\text { Is COVID- } 19 \text { the main transmission } \\
\text { method by droplet transmission and } \\
\text { contact transmission? }\end{array}$} & & No or Unclear & 2075 & $\begin{array}{l}22.35 \pm \\
7.23\end{array}$ & 1.653 & 0.098 & 238(44.32) & 5.62 & 0.018 \\
\hline & & Yes & 374 & $\begin{array}{l}21.68 \pm \\
7.06\end{array}$ & & & 739(38.65) & & \\
\hline \multirow[t]{2}{*}{ Could antibiotics prevent COVID-19? } & & No or Unclear & 537 & $\begin{array}{l}22.88 \pm \\
7.31\end{array}$ & 2.321 & 0.02 & $209(44.75)$ & 5.684 & 0.017 \\
\hline & & Yes & 1912 & $\begin{array}{l}22.07 \pm \\
7.16\end{array}$ & & & 768(38.75) & & \\
\hline \multirow[t]{2}{*}{$\begin{array}{l}\text { taking shuanghuanglian oral liquid could } \\
\text { prevent COVID-19? }\end{array}$} & & No or Unclear & 467 & $\begin{array}{l}23.07 \pm \\
6.84\end{array}$ & 2.761 & 0.006 & 212(44.92) & 6.148 & 0.013 \\
\hline & & Yes & 1982 & $\begin{array}{l}22.05 \pm \\
7.27\end{array}$ & & & 765(38.69) & & \\
\hline \multirow[t]{2}{*}{$\begin{array}{l}\text { Could room fumigated vinegar kill SARS- } \\
\text { CoV-2? }\end{array}$} & & No or Unclear & 472 & $\begin{array}{l}23.33 \pm \\
6.92\end{array}$ & 3.664 & $<0.001$ & 277(43.97) & 5.872 & 0.015 \\
\hline & & Yes & 1977 & $\begin{array}{l}21.99 \pm \\
7.25\end{array}$ & & & $700(38.48)$ & & \\
\hline \multirow[t]{2}{*}{$\begin{array}{l}\text { Could hot water at } 56 \text { degrees celsius kill } \\
\text { SARS-CoV-2 for } 30 \text { minutes? }\end{array}$} & & No or Unclear & 630 & $\begin{array}{l}22.92 \pm \\
6.97\end{array}$ & 2.719 & 0.007 & $839(40.43)$ & 1.652 & 0.199 \\
\hline & & Yes & 1819 & $\begin{array}{l}22.01 \pm \\
7.27\end{array}$ & & & 138(36.90) & & \\
\hline \multirow[t]{2}{*}{$\begin{array}{l}\text { Mask types that can prevent viral } \\
\text { infections }\end{array}$} & & No or Unclear & 2128 & $\begin{array}{l}22.31 \pm \\
7.21\end{array}$ & 1.13 & 0.259 & $854(40.13)$ & 0.383 & 0.536 \\
\hline & & Yes & 321 & $\begin{array}{l}21.82 \pm \\
7.17\end{array}$ & & & 123(38.32) & & \\
\hline \multirow[t]{4}{*}{ cognition of susceptibility to COVID-19 } & a & $\begin{array}{l}\text { Weak or } \\
\text { extremely weak }\end{array}$ & 36 & $\begin{array}{l}23.58 \pm \\
7.04\end{array}$ & 4.466 & 0.004 & $21(58.33)$ & 21.656 & $<001$ \\
\hline & b & General & 50 & $\begin{array}{l}25.08 \pm \\
5.39 \mathrm{~d}\end{array}$ & & & $32(64.00) \mathrm{cd}$ & & \\
\hline & c & Strong & 813 & $\begin{array}{l}22.58 \pm \\
6.86\end{array}$ & & & $340(41.82) b$ & & \\
\hline & d & very strong & 1550 & $\begin{array}{l}21.95 \pm \\
7.4 b\end{array}$ & & & $584(37.68) b$ & & \\
\hline \multirow[t]{4}{*}{ life-threaten level } & a & $\begin{array}{l}\text { Not afraid or } \\
\text { nothing afraid }\end{array}$ & 278 & $\begin{array}{l}19.65 \pm \\
8.26 \mathrm{bcd}\end{array}$ & 21.977 & $<.001$ & $91(32.73) \mathrm{cd}$ & 25.367 & $<001$ \\
\hline & $b$ & average & 768 & $\begin{array}{l}21.62 \pm \\
6.93 \mathrm{acd}\end{array}$ & & & 267(34.77)cd & & \\
\hline & c & afraid & 964 & $\begin{array}{l}22.89 \pm \\
6.82 \mathrm{ab}\end{array}$ & & & 419(43.46)ab & & \\
\hline & d & very afraid & 439 & $\begin{array}{l}23.57 \pm \\
7.26 a b\end{array}$ & & & $200(45.56) a b$ & & \\
\hline \multirow[t]{3}{*}{ The perceived severity of the COVID-19 } & a & $\begin{array}{l}\text { Not serious or } \\
\text { nothing serious }\end{array}$ & 53 & $\begin{array}{l}23.19 \pm \\
6.75\end{array}$ & 0.446 & 0.721 & $25(47.17)$ & 3.074 & 0.38 \\
\hline & $b$ & average & 131 & $\begin{array}{l}21.9 \pm \\
7.49\end{array}$ & & & $59(45.04)$ & & \\
\hline & c & Serious & 972 & $\begin{array}{l}22.18 \pm \\
6.97\end{array}$ & & & $389(40.02)$ & & \\
\hline
\end{tabular}

a: compared with the first layer, $P<0.05$; b: compared with the second layer, $P<0.05$; c: compared with the third layer, $P<0.05$; $\mathrm{d}$ : compared with the fourth layer, $P<0.05$. 


\begin{tabular}{|c|c|c|c|c|c|c|c|c|c|}
\hline & Label & & $\mathbf{N}$ & $\begin{array}{l}\text { Perceived } \\
\text { stress } \\
\text { score }\end{array}$ & $t / F$ & $\mathbf{P}$ & $\begin{array}{l}\text { Health risk } \\
\text { stress }\end{array}$ & $x^{2}$ & $P$ \\
\hline & d & strongly serious & 1293 & $\begin{array}{l}22.29 \pm \\
7.37\end{array}$ & & & 504(38.98) & & \\
\hline \multirow[t]{4}{*}{$\begin{array}{l}\text { The importance of home isolation during } \\
\text { the COVID-19 }\end{array}$} & a & $\begin{array}{l}\text { extremely } \\
\text { unclear or } \\
\text { relatively unclear }\end{array}$ & 26 & $\begin{array}{l}23.77 \pm \\
6.47 \mathrm{~b}\end{array}$ & 20.432 & $<.001$ & 12(46.15)b & 49.558 & $<001$ \\
\hline & $b$ & uncertainty & 45 & $\begin{array}{l}27.33 \pm \\
3.52 \text { acd }\end{array}$ & & & 36(80.00)acd & & \\
\hline & c & quite clear & 420 & $\begin{array}{l}24.04 \pm \\
6.36 b\end{array}$ & & & 203(48.33)b & & \\
\hline & d & strongly clear & 1958 & $\begin{array}{l}21.72 \pm \\
7.34 b\end{array}$ & & & 726(37.08)b & & \\
\hline \multirow[t]{4}{*}{$\begin{array}{l}\text { The Difference between COVID-19 and } \\
\text { Common Cold }\end{array}$} & $a$ & $\begin{array}{l}\text { extremely } \\
\text { unclear or } \\
\text { relatively unclear }\end{array}$ & 73 & $\begin{array}{l}26.04 \pm \\
5.67 \mathrm{bcd}\end{array}$ & 30.254 & $\stackrel{<}{0.001}$ & $46(63.01) \mathrm{cd}$ & 48.152 & $<.001$ \\
\hline & $b$ & uncertainty & 280 & $\begin{array}{l}24.51 \pm \\
6.53 a c d\end{array}$ & & & 144(51.43)cd & & \\
\hline & c & quite clear & 1167 & $\begin{array}{l}22.61 \pm \\
6.77 \mathrm{abd}\end{array}$ & & & 476(40.79)abd & & \\
\hline & d & strongly clear & 929 & $\begin{array}{l}20.81 \pm \\
7.69 a b c\end{array}$ & & & 311(33.48)abc & & \\
\hline \multirow[t]{4}{*}{$\begin{array}{l}\text { Is there any confirmed or suspected } \\
\text { COVID- } 19 \text { patient within } 1 \mathrm{~km} \text { of yourself }\end{array}$} & a & $\begin{array}{l}\text { extremely } \\
\text { unclear or } \\
\text { relatively unclear }\end{array}$ & 114 & $\begin{array}{l}23.58 \pm \\
6.87 d\end{array}$ & 25.292 & $<.001$ & $53(46.49) d$ & 30.664 & $<.001$ \\
\hline & $b$ & uncertainty & 498 & $\begin{array}{l}23.68 \pm \\
6.6 \mathrm{~d}\end{array}$ & & & $230(46.18) d$ & & \\
\hline & c & quite clear & 792 & $\begin{array}{l}23.03 \pm \\
6.63 d\end{array}$ & & & $342(43.18) d$ & & \\
\hline & d & strongly clear & 1045 & $\begin{array}{l}20.82 \pm \\
7.67 \mathrm{abc}\end{array}$ & & & 352(33.68)abc & & \\
\hline
\end{tabular}

\subsection{Multivariate Analysis of Health Risk Stress}

We found that $39.89 \%$ of the residents were in a state of health risk stress. Demographic characteristics and cognitive items were included in the univariate logistic regression analysis, and 13 variables (gender, marriage, occupation, monthly income, etc.) were included in the multivariate logistic regression analysis. The data showed that age, cognition of susceptibility to COVID-19, life-threaten levels, cognition of the importance of home isolation, and cognition of the difference between common cold and COVID-19 were significantly related to the occurrence of health risk stress among residents, $P<0.05$. Table 4. 
Table 4

Logistic Regression Model Results of Health Risk Stress Incidence among participants

\begin{tabular}{|c|c|c|c|c|c|c|c|}
\hline Variable & & $\beta$ & Stderr & $\begin{array}{l}\text { Wald } \\
\chi^{2}\end{array}$ & $\mathbf{P}$ & OR & $95 \% \mathrm{Cl}$ \\
\hline \multicolumn{8}{|c|}{ Age(years) } \\
\hline & $18-25$ & 0.94 & 0.165 & 32.444 & $<.001$ & 2.561 & $1.853,3.539$ \\
\hline & $26-30$ & 0.817 & 0.177 & 21.372 & $<.001$ & 2.264 & $1.601,3.201$ \\
\hline & $31-40$ & 0.268 & 0.182 & 2.18 & 0.14 & 1.308 & $0.916,1.867$ \\
\hline & $41-50$ & 0.077 & 0.179 & 0.187 & 0.665 & 1.08 & $0.761,1.534$ \\
\hline & $\geqq 51$ & & & & & 1.0 (reference) & \\
\hline \multicolumn{8}{|c|}{ Cognition of susceptibility to COVID-19 } \\
\hline & very strong & 1.069 & 0.363 & 8.666 & 0.003 & 2.912 & $1.429,5.934$ \\
\hline & Strong & 0.994 & 0.325 & 9.361 & 0.002 & 2.703 & $1.43,5.111$ \\
\hline & General & 0.166 & 0.096 & 2.982 & 0.084 & 1.181 & $0.978,1.425$ \\
\hline & Weak or extremely weak & & & & & 1.0 (reference) & \\
\hline \multicolumn{8}{|c|}{ Life-threaten level } \\
\hline & Not afraid or nothing afraid & & & & & 1.0(reference) & \\
\hline & average & -0.078 & 0.159 & 0.239 & 0.625 & 0.925 & $0.678,1.263$ \\
\hline & afraid & 0.426 & 0.153 & 7.763 & 0.005 & 1.531 & $1.135,2.065$ \\
\hline & very afraid & 0.706 & 0.17 & 17.166 & $\dot{0.001}$ & 2.026 & $1.451,2.829$ \\
\hline \multicolumn{8}{|c|}{$\begin{array}{l}\text { The importance of home isolation during the } \\
\text { COVID-19 epidemic }\end{array}$} \\
\hline & $\begin{array}{l}\text { extremely unclear or } \\
\text { relatively unclear }\end{array}$ & 0.027 & 0.437 & 0.004 & 0.95 & 1.028 & $0.437,2.418$ \\
\hline & uncertainty & 1.452 & 0.398 & 13.315 & $<.001$ & 4.27 & $1.958,9.313$ \\
\hline & quite clear & 0.293 & 0.119 & 6.116 & 0.013 & 1.341 & $1.063,1.691$ \\
\hline & strongly clear & & & & & 1.0 (reference) & \\
\hline \multicolumn{8}{|c|}{$\begin{array}{l}\text { The Difference between COVID-19 and Common } \\
\text { Cold }\end{array}$} \\
\hline & $\begin{array}{l}\text { extremely unclear or } \\
\text { relatively unclear }\end{array}$ & 0.977 & 0.274 & 12.664 & $<.001$ & 2.656 & $1.551,4.548$ \\
\hline & uncertainty & 0.624 & 0.151 & 17.182 & $\dot{0} 001$ & 1.866 & $1.39,2.507$ \\
\hline & quite clear & 0.214 & 0.099 & 4.699 & 0.03 & 1.239 & $1.021,1.503$ \\
\hline
\end{tabular}

\section{4.discussion}

We conducted an internet survey on 2449 Chinese residents of perceived stress and health behaviors during the COVID-19 outbreak. The 45th Statistical Report on Internet Development in China showed that China's internet population was 904 million, with the internet popularizing rate reaching 64.5\% [14]. Previously, some studies had also used internet survey and confirmed that it was time-saving and convenient Compared with the traditional paper questionnaire survey $[15,16]$.

\section{High risk groups of health risk stress}

Students had higher stress scores, previously, the prevalence of perceived stress among students was high [17]. At the current stage, universities delayed the start of the semester, the ministry of education advocated the suspension of classes, and stress from unexpected events, that was COVID-19, all of them had adverse effects on students. Outbreaks can put significant psychological stress that may lead to unfavorable effects on learning and the overall psychological health of students [18], While distressing their overall psychological health, this situation could adversely affect learning, by the increased 
avoidance of learning activities and reducing their concentrations. all of these results highlight the need to establish psychological support programs for students during an COVID-19 outbreak. Besides, there is no doubt that the mental health of the isolated population deserved attention, these individuals needed more social support and professional Psychological crisis interventions.

Further, Medical personnel were also the focus of attention. Initially, the health care workers were placed in a stressful condition due to the uncertainty about the mode of transmission of the disease, tremendous fear, and implementation of rigorous infection control protocols, It had been found that $30 \%$ of confirmed cases were health care workers (HCWs)during Middle East Respiratory Syndrome-Corona Virus outbreaks, During the SARS epidemic in 2003 and the influenza A/Hemagglutinin1 Neuraminidase1(H1N1) pandemic in 2009, researchers evaluated psychological stress on HCWs using different modalities, and stress was found constantly high [18]. This study showed that $45.19 \%$ of medical workers were in a state of health risk stress, a large burden in the clinical treatment and public prevention efforts in hospitals and community settings. such psychological distress may affect HCWs, who would be in a high demand and shortage during outbreaks. Challenges and stress they experienced could trigger common mental disorders, including anxiety and depressive disorders, and posttraumatic stress disorder, which in turn could result in hazards that exceed the consequences of the epidemic itself [19, 20]. For on-thejob medical personnel, they should further strengthen their awareness of self-protection, emphasize strict implementation of infectious disease protection measures, standardize operations, maintain a peaceful mindset, and relieve stress in a timely manner. The hospital should provide timely management and technical support, allocate and guarantee supplies, and provide online and offline psychological counseling services.

Totally, there were at least three types of residents with extremely high stress. In order to improve efficiency and make good use of limited medical resources, it is important to establish key target groups at the initial stage and set priorities accordingly. Nowadays, The guidelines divided the population affected by COVID-19 into four levels, the first level included medical staff, especially in the front line, the second level included suspected people, and the forth level contained susceptible groups and general public [21]. It was essential to incorporate stress buster or psychological therapists into the overall deployment of COVID-19 epidemic prevention and control, the main premise of stress buster or psychological therapists is to minimize psychological harm and provide timely assistance for epidemic prevention and control, that is to say, to provide mental health support for high risk stress individuals. The work of Psychological intervention was initiated by the Chinese Society of Psychiatry, with a team of experts established to organize intervention efforts and provide technical guidance [22]. In the current epidemic status, face-to-face psychological counseling requires high standards of on-site isolation to minimize risks. This service is only available to front-line medical staff who have not been infected, so it is not suitable for ordinary residents who need psychological intervention. In order to ensure the continuous provision of mental health services and reduce the risk of cross-infection, the Chinese government is developing and implementing a remote consultation network to conduct telephone or internet consultations in a safe environment [21]. Negative Relationship between health Behavior and perceived Stress

Individual's perceived stress often exert significant effects on behavior habit and experience [23], Data analysis of residents' health behaviors and different stress states were statistically significant $(p<0.05)$. Which is consistent with the results of the impact of perceived stress on health behaviors investigated by the work during the SARS epidemic [5]. At present, it is generally believed that stress is a process and the product of the interaction between human and environment, which mainly includes the mediating variable of stress source and the physical and mental response. It has been suggested that there are three types of response that can help the body respond to stressors, namely direct stress responses. This kind of response can make the body respond quickly to fight or escape when it responds to stressors. Adaptability of secondary signals of the body and brain; and an assessment of stress responses based on cortical structures and pathways involved in cognitive processes through which the subject responds to the stressor [8]. For the domestic material reserve status, this survey found that $71.37 \%$ of the residents had little or no masks when the epidemic broke out, while only $6.16 \%$ had more or sufficient disinfectant. The shortage of supplies and the sudden disruption of work and life may all become main sources of stress for residents during the epidemic of COVID-19. We also found residents with monthly income more than 10,000 RMB have lower rates of perceived stress and health risk stress, so we had to admit that the economic situation was also an important factor that should not be ignored.

The link between perceived cognitive deficits and depressive symptoms is partially explained by quality of sleep and perceptions of stress [24], anxiety, as well. Anxiety levels closely mirrored the daily number of new cases and were strongly associated with the intensity of the outbreak [25]. Psychobehavioral responses during the SARS or H1N1 influenza outbreaks showed a positive association between anxiety level and personal protective behaviors [25-27], however, if the anxiety level continues to rise, it will have adverse effects, the previous study also showed the same results [28]. Logistic regression models were also used to examine the prevalence of high levels of perceived stress and poor sleep quality, increased in proportion to the heavy smartphone use and insufficient physical activity [29]. This work showed that only $53.33 \%$ of residents often or always take appropriate exercise even when they are isolated in home. Relevant study [30] have shown that staying at home for a long period of time may lead to increased sedentary behaviors, thereby reducing regular physical activity, eventually leading to increased health risks or causing a cycle of anxiety, depression, and vice. Therefore, it is suggested to strengthen residents' health behaviors, pay attention to a balanced diet, maintain regular exercise and improve immunity in a safe family environment.

\section{Residents' cognition of disease is not optimistic under stress state}

As for knowledge, approximately $63 \%$ answered two or more questions correctly regarding knowledge of SARS [28]. Nowadays, the overall disease awareness rate was $62.04 \%$ of COVID-19. This disease hasn't been fully understood, there is currently no specific drug or vaccine, the need for disease information and health behaviors by official authorities is also high. This survey showed that $73.71 \%$ of the residents were very concerned about the epidemic information, which is accurate, clear, sufficient, timely, and trustworthy. Public health authorities should keep monitoring the situation, as the more we learn about this novel virus and its associated outbreaks, the better we can respond [31]. The media and governments at all levels should enrich the channels and methods of information disclosure, strengthen the education of disease-related knowledge, and release epidemic information in real time to meet the needs of different groups. Residents should take a rational view of COVID-19, abide by the special regulations during the epidemic, increase

Page $12 / 15$ 
awareness of prevention, obtain information through official channels, relieve stress, understand the importance of home isolation, and avoid virus transmission.

\section{Notable factors affecting health risk stress}

The onset of a sudden and immediately life-threatening illness could lead to high stress status [32]. This study found that $39.89 \%$ of the residents were in a state of health risk stress. A number of important factors triggered residents' health risk stress. Perceived life threaten emerged as the most significant predictor for the Impact of Event Scale-Revised (IES-R)and Hospital and Anxiety Scale (HADS) scores that reflect stress-based symptoms [32], In literature for a broader range of stress status, other predictor variables such as gender, age, and perceived life threat were found [33], further, this study showed that residents who were younger, with higher disease susceptibility perception, higher life threaten level, uncertain home isolation importance or extremely unclear about the difference between Common cold and COVID-19, significantly associated with health risk stress. It is necessary to take effective measures to deal with health risk stress based on these factors can be intervened.

This study had several highlights. Firstly, to minimize personal contact during the outbreak, participants were surveyed by internet instead of face-to-face, internet survey is different from traditional investigation methods, it is rapid and convenient. Secondly, this work revealed some specific individuals need to be deeply concerned. Lastly, effective psychological interventions for residents keep mental health against COVID-19 are needed, we put forward some suggestions for psychological interventions. However, this study had a few vital limitations. One is the potential selection bias of the study participants, although it covered the residents of 20 provinces, did not represent the status of all Chinese. Yet, due to a rather big number of the responses, it still makes sense, and showed the overall trend. Furthermore, we had to acknowledge the limitation of uncontrollable.

\section{5 .conclusion}

This study provided a timely and authentic data on perceived stress in relation COVID-19. In conclusion, in the present internet survey revealed that the female, students, medical staff and residents who were in medical or home isolation observation, had higher stress scores. Furthermore, $39.89 \%$ of residents are under health risk stress, The resident who were younger, perception of higher disease susceptibility, higher life threaten level, uncertainty of the importance of home isolation or extremely unclear about the difference between Common cold and COVID-19, significantly associated with health risk stress. In addition, with the increase of perceived stress, the frequency of health behaviors decreases. The significant factors found in this work may help to identify the at-risk resident for timely and necessary interventions.

\section{6 .declarations}

\subsection{Acknowledgements}

The authors would like to thank all anonymous participants for filling out the questionnaire in the survey.

\subsection{Authors contributions}

All authors have made substantial contributions to the work are as follows. Lili Yao, BSN, Master Candidate, RN, contributed to study design and article drafting. Yetao Luo, MAS, contributed to study design, data analysis, and data interpretation. Feng Yuan, BSN, RN, contributed to study design and data collection. Lupei Yan, BSN, Master Candidate, RN, contributed to data collection. Yuerong Li, MSN, RN, Associate professor, contributed to thoroughly revised the manuscript. All authors read and approved the final manuscript.

\subsection{Funding}

This research did not receive any specific grant from funding agencies in the public, commercial, or not-for-profit sectors.

\subsection{Availability of data and materials}

All data and materials used in this work were publicly available.

\subsection{Ethics approval and consent to participate}

This study was approved by the Ethics Committee of the First Affiliated Hospital of Chongqing Medical University(No.2020-250). Informed consent was obtained for all participants.

\subsection{Consent for publication}

Not applicable

\subsection{Competing interests}

The authors declare no competing interests.

\section{Abbreviations}


COVID-19: 2019 novel coronavirus disease; CPSS: Chinese perceived stress scale; HADS: Hospital and Anxiety Scale; HCWs: health care workers; H1N1: Hemagglutinin1 Neuraminidase 1; IES-R:Impact of Event Scale-Revised; PSS: The perceived stress scale; SARS: severe acute respiratory syndrome; WHO: World Health Organization.

\section{References}

1. Lee DT, Sahota D, Leung TN, Yip AS, Lee FF, Chung TK. Psychological responses of pregnant women to an infectious outbreak: a case-control study of the 2003 SARS outbreak in Hong Kong. J Psychosom Res. 2006;61(5):707-713. doi:10.1016/j.jpsychores.2006.08.005.

2. WHO, 2020, Statement on the second meeting of the International Health Regulations (2005) Emergency Committee regarding the outbreak of novel coronavirus (2019-nCoV). https://www.who.int/news-room/detail/30-01-2020-statement-on-the-second-meeting-of-the-international-health-regulations(2005)-emergency-committee-regarding-the-outbreak-of-novel-coronavirus-(2019-ncov).

3. WHO, 2020, Coronavirus disease 2019 (COVID-19)Situation Report-103. Availabe online: https://www.who.int/emergencies/diseases/novelcoronavirus-2019/situation-reports (accessed on 2 May 2020).

4. Kashdan TB, Barrios V, Forsyth JP, Steger MF. Experiential avoidance as a generalized psychological vulnerability: comparisons with coping and emotion regulation strategies. Behav Res Ther. 2006;44(9):1301-1320. doi:10.1016/j.brat.2005.10.003.

5. S Lu, B Tian, T Yang, D Chen. analysis of the related behavioral influencing factors on the publicr health during SARS outbreak.Modern Preventive Medicine.2008;35(15): 2907-2909.doi:10.3969/j.issn.1003-8507.2008.15.037.

6. B Tian, T Yang, S Lu, D Chen, B Zhu, H Chi. The changes of health related behavior during and after severe acute respiratory sydrome prevalence.Chinese Journal of Preventive Medicine.2007;41(4): 254-257.doi:10.3760/j:issn:0253-9624.2007.04.004.

7. Cohen S, Kamarck T, Mermelstein R. A global measure of perceived stress. J Health Soc Behav. 1983;24(4):385-396.

8. Katsarou A, Panagiotakos D, Zafeiropoulou A, et al. Validation of a Greek version of PSS-14; a global measure of perceived stress. Cent Eur J Public Health. 2012;20(2):104-109.

9. T Yang, H Huang..An epidemiological study on stress among urban residents in social transition period.Chin J Epidemiol. 2003; 24(9): 760764.doi:10.3760/j.issn:0254-6450.2003.09.004.

10. Chiodini J. Maps, masks and media - Traveller and practitioner resources for 2019 novel coronavirus (2019-nCoV) acute respiratory virus. Travel Med Infect Dis. 2020;33:101574. doi:10.1016/j.tmaid.2020.101574.

11. The Lancet.Emerging understandings of 2019-nCoV.Lancet.2020;395(10221):311. doi:10.1016/S0140-6736(20)30186-0.

12. Coronavirus disease (COVID-19) advice for the public. Availabe online: https://www.who.int/emergencies/diseases/novel-coronavirus-2019/advice-forpublic (accessed on 5 February 2020).

13. National Health Commission of the People's Republic of China. Coronavirus disease (COVID-19) knowledge of prevention. Availabe online: http://www.nhc.gov.cn/xcs/kpzs/list_gzbd.shtml (accessed on 5 February 2020).

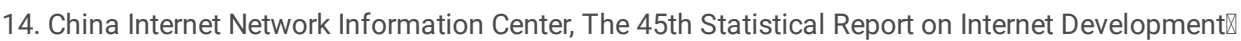
http://cnnic.cn/hlwfzyj/hlwxzbg/hlwtjbg/202004/P020200428399188064169.pdf (accessed on 28 April 2020)

15. Motoo Y, Yukawa K, Hisamura K, Tsutani K, Arai I. Internet survey on the provision of complementary and alternative medicine in Japanese private clinics: a cross-sectional study. J Integr Med. 2019;17(1):8- doi:10.1016/j.joim.2018.11.003.

16. Campbell RM, Venn TJ, Anderson NM. Cost and performance tradeoffs between mail and internet survey modes in a nonmarket valuation study. J Environ Manage. 2018;210:316-327. doi:10.1016/j.jenvman.2018.01.034.

17. Fasoro AA, Oluwadare T, Ojo TF, Oni IO. Perceived stress and stressors among first-year undergraduate students at a private medical school in Nigeria. J Taibah Univ Med Sci. 2019;14(5):425-430. Published 2019 Sep 28. doi:10.1016/j.jtumed.2019.08.003.

18. Al-Rabiaah A, Temsah MH, Al-Eyadhy AA, et al. Middle East Respiratory Syndrome-Corona Virus (MERS-CoV) associated stress among medical students at a university teaching hospital in Saudi Arabia [published online ahead of print, 2020 Jan 27]. J Infect Public Health. 2020;S18760341(20)30005-8. doi:10.1016/j.jiph.2020.01.005.

19. Shultz JM, Baingana F, Neria Y. The 2014 Ebola outbreak and mental health: current status and recommended response. JAMA. 2015;313(6):567-568. doi:10.1001/jama.2014.17934.

20. Bao Y, Sun Y, Meng S, Shi J, Lu L. 2019-nCoV epidemic: address mental health care to empower society. Lancet. 2020;395(10224):e37-e38. doi:10.1016/S0140-6736(20)30309-3.

21. Xixi Jiang , Lili Deng, Yuncheng Zhu , Haifeng Ji , Lily Tao , Li Liu , Daoliang Yang , Weidong Ji , Psychological crisis intervention during the outbreak period of new coronavirus pneumonia from experience in Shanghai, Psychiatry Research (2020), doi: https://doi.org/10.1016/j.psychres.2020.112903.

22. Chinese Society of Psychiatry, 2020. Expert consensus on managing pathway and coping strategies for patients with mental disorders during prevention and control of serious and outbreak infectious diseases (novel coronavirus pneumonia). Chin J Psychiatry 53, E002. https://doi: 10.3760/cma.j.cn113661-20200219-00039.

23. Liu C, Liu Y, Gedeon T, Zhao Y, Wei Y, Yang F. The effects of perceived chronic pressure and time constraint on information search behaviors and experience[J]. Information Processing \& Management. 2019;56(5): 1667-1679.

24. Lamis DA, Hirsch JK, Pugh KC, et al. Perceived cognitive deficits and depressive symptoms in patients with multiple sclerosis: Perceived stress and sleep quality as mediators. Mult Scler Relat Disord. 2018;25:150-155. doi:10.1016/j.msard.2018.07.019.

Page $14 / 15$ 
25. Leung, G.M., Ho, L.M., Chan, S.K., Ho, S.Y., Bacon-Shone, J., Choy, R.Y., et al. Longitudinal assessment of community psychobehavioral responses during and after the 2003 outbreak of severe acute respiratory syndrome in Hong Kong. Clin. Infect. Dis. 2005;40 (12), 1713-1720.

26. Seto WH, Tsang D, Yung RW, et al. Effectiveness of precautions against droplets and contact in prevention of nosocomial transmission of severe acute respiratory syndrome (SARS). Lancet. 2003;361(9368):1519-1520. doi:10.1016/s0140-6736(03)13168-6.

27. Wong LP, Sam IC. Temporal changes in psychobehavioral responses during the 2009 H1N1 influenza pandemic. Prev Med. 2010;51(1):92-93. doi:10.1016/j.ypmed.2010.04.010.

28. Quah Stella R,Hin-Peng Lee,Crisis prevention and management during SARS outbreak, Singapore.[J] .Emerging Infect. Dis.2004;10(2): 364-368. doi:10.3201/eid1002.030418.

29. Zhai X, Ye M, Wang C, Gu Q, Huang T, Wang K, Chen Z, Fan X. Associations among physical activity and smartphone use with perceived stress and sleep quality of Chinese college students[J]. Mental Health and Physical Activity,2020;18: 100323.https://doi.org/10.1016/j.mhpa.2020.100323.

30. Chen P, Mao L, Nassis GP, Harmer P, Ainsworth BE, Li F. Wuhan coronavirus (2019-nCoV): The need to maintain regular physical activity while taking precautions. J Sport Health Sci. 2020;9(2):103-104. doi:10.1016/j.jshs.2020.02.001.

31. Lai CC, Shih TP, Ko WC, Tang HJ, Hsueh PR. Severe acute respiratory syndrome coronavirus 2 (SARS-CoV-2) and coronavirus disease-2019 (COVID-19): The epidemic and the challenges [published online ahead of print, 2020 Feb 17]. Int J Antimicrob Agents. 2020;105924. doi:10.1016/j.ijantimicag.2020.105924.

32. Wu KK, Chan SK, Ma TM. Post traumatic stress, anxxiety, and depression in survivors of severe acute respiratory syndrome (SARS). J Trauma Stress. 2005;18(1):39-42.

33. Brewin CR, Andrews B, Valentine JD. Meta-analysis of risk factors for posttraumatic stress disorder in trauma-exposed adults. J Consult Clin Psychol. 2000;68(5):748-766. doi:10.1037//0022-006x.68.5.748. 